\title{
Federal Reserve Policy AND THE Housing BubBLE
}

\section{Lawrence H. White}

The U.S. housing bubble and the fallout from its bursting are not the results of a laissez-faire monetary and financial system. They happened in an unanchored government fiat monetary system with a restricted financial system.

\section{What Happened and Why?}

Our current financial turmoil began with unusual monetary policy moves by the Federal Reserve System and novel federal regulatory interventions. These poorly chosen public policies distorted interest rates and asset prices, diverted loanable funds into the wrong investments, and twisted normally robust financial institutions into unsustainable positions. There is no doubt that private miscalculation and imprudence have made matters worse for more than a few institutions. Such mistakes help to explain which particular firms have run into the most trouble. But to explain industry-wide errors we need to identify price and incentive distortions capable of having industry-wide effects.

Here I will make two main points. First, the Federal Reserve's expansionary monetary policy supplied the means for unsustainable housing prices and unsustainable mortgage financing. Elsewhere (White 2008) I have discussed the growth in regulatory mandates and subsidies that exaggerated the demand for riskier mortgages, most importantly the implicit guarantees to Fannie Mae and Freddie

Cato Journal, Vol. 29, No. 1 (Winter 2009). Copyright (C) Cato Institute. All rights reserved.

Lawrence H. White is the F. A. Hayek Professor of Economic History at the University of Missouri-St. Louis. 
Mac that combined with HUD's imposition of "affordable housing"mandates on Fannie and Freddie to accelerate the creation of a market for securitized subprime mortgages. ${ }^{1}$ Second, the Federal Reserve has undertaken self-initiated new lending roles that constitute a shadow bailout program more than twice the size of the Treasury's $\$ 700$ billion bailout program. There is unfortunately little evidence that the Fed's new lending has helped to resolve our financial problems, rather than to delay their resolution.

\section{The Credit Supply Bubble}

Some authors, considering the relationship of Federal Reserve policy to asset bubbles, ask only: Should the Fed actively burst a growing bubble? If so, how? As posed, their questions suggest that asset bubbles arise independent of monetary policy, and the only Fed role to be discussed is that of bubble-buster. A more important pair of questions is: Does Fed policy as currently conducted tend to inflate assets bubbles? If so, how can we reformulate policy to avoid that tendency? Call our objective a non-bubble-prone or "non-effervescent" monetary policy. The economics profession has not reached a consensus on what the optimally non-effervescent monetary policy is, but it is now widely agreed that it isn't holding interest rates too low for too long. It should also now be clear that a Fed policy that deliberately ignores asset prices, as though consumer prices alone were a sufficient indicator of excessive Fed expansion, is also not the way to avoid inflating asset bubbles.

In the recession of 2001, the Federal Reserve System under Chairman Alan Greenspan began aggressively expanding the U.S. money supply. Year-over-year growth in the M2 monetary aggregate rose briefly above 10 percent, and remained above 8 percent entering the second half of 2003. The expansion was accompanied by the Fed's repeatedly lowering its target for the federal funds (interbank overnight) interest rate. The Fed funds rate began 2001 at 6.25 percent and ended the year at 1.75 percent. The Greenspan Fed reduced the rate further in 2002 and 2003, pushing it in mid-2003 a record low of 1 percent, where it stayed for a year. The real Fed funds rate was negative-meaning that nominal rates were lower than the contemporary rate of inflation-for an unprecedented two and a half years. A borrower during that period who simply purchased and held vacant

${ }^{1}$ The discussion of Fed policy in the next section also draws on White (2008). 
land, the price of which (net of taxes) merely kept up with inflation, was profiting in proportion to what he borrowed.

How do we judge whether the Fed expanded more than it should have? One venerable (albeit no longer popular) norm for making fiat central bank policy as neutral as possible toward the financial market is to aim for stability (zero growth) in the volume of nominal expenditure. In the equation of exchange, $\mathrm{MV}=\mathrm{Py}$, nominal expenditure is $\mathrm{MV}$ or equivalently Py. Stability of MV implies that the Fed should not inject money through the financial market to offset growth in real output (y) due to increasing productivity. Instead it should allow consumer goods prices to fall when productivity gains reduce the costs of production (see Selgin 1997). Second-best to stability of nominal expenditure would be a predictably low and steady growth rate. One useful measure of nominal expenditure is the dollar volume of final sales to domestic purchasers (GDP less net exports and change in business inventories). During the two years from the start of 2001 to the end of 2002, final sales to domestic purchasers grew at a positive but moderate compounded rate of 3.6 percent per annum. During 2003 the Fed's expansion of demand began to show up: the growth rate jumped to 6.5 percent. For the next two years, from the start 2004 to the end of 2005 , the growth rate was even higher at 7.1 percent, nearly a doubling of the initial rate. It then backed off, to 4.3 percent per annum from the start of 2006 to the start of 2008. But the damage from an unusually rapid expansion of nominal demand had been done. ${ }^{2}$

A widely used norm for Fed policy is the "Taylor Rule," a formula devised by economist John Taylor of Stanford University. The Taylor Rule offers a method of estimating the level of the federal funds rate that would be consistent (conditional on current inflation and real income) with keeping the economy's price inflation rate to a chosen target rate. From early 2001 until late 2006 the Fed kept the federal funds rate on a path well below the estimated rate that would have been consistent with targeting a 2 percent inflation rate (the highest rate within the Bernanke Fed's declared "comfort zone"). A fortiori the Fed held the actual rate even farther below the path consistent with targeting stability in nominal income. In its monthly publication Monetary Trends, the Federal Reserve Bank of St. Louis plots the estimated range of federal funds rates that would be consistent with inflation rates of 0 to 4 percent.

${ }^{2}$ Federal Reserve Bank of St. Louis FRED database, Series FSDP, Final Sales to Domestic Purchasers, http://research.stlouisfed.org/fred2/series/FSDP?cid=106. 


\section{Cato Journal}

Its plots show that the Taylor-rule gap was especially large—200 basis points or more-from mid-2003 to mid-2005. ${ }^{3}$

Alan Greenspan has pled innocent to the charge of having overexpanded and created a credit bubble, on the grounds that (1) the housing price bubble was worldwide, thus the growth of U.S. credit must have reflected a global savings glut, and (2) the monetary base and M2 weren't growing rapidly. There appears to be a grain of truth to the hypothesis that growth in the global supply of loanable funds to the U.S. market pushed down U.S. real interest rates. Real 30-year mortgage rates in the United States, largely beyond the influence of Federal Reserve policy, did fall. Nominal 30-year rates fell by 113 basis points between 2001 and 2004 while the inflation rate fell only 15 basis points. As noted above, however, the Fed lowered the federal funds rate much more, by 525 basis points, indicating a major amplification of cheap credit by Fed policy. M2 growth, as noted above, in fact remained unusually high for at least two years. Consequently, Greenspan's claim that money growth was slow cannot be substantiated.

The dramatic lowering of short-term interest rates not only fueled growth in the dollar volume of mortgage lending, but had unintended consequences for the type of mortgages written. By pushing veryshort-term interest rates down so dramatically between 2001 and 2004, the Fed lowered short-term rates relative to 30-year rates. Adjustable-rate mortgages (ARMs), typically based on a one-year interest rate, became increasingly cheap relative to 30-year fixed-rate mortgages. Back in 2001, nonteaser ARM rates on average were 113 basis points cheaper than 30 -year-fixed mortgage rates (5.84 percent vs. 6.97 percent). By 2004, as a result of the ultra-low federal funds rate, the gap had grown to 194 basis points (3.90 percent vs. 5.84 percent). ${ }^{4}$ Not surprisingly, increasing numbers of new mortgage borrowers were drawn away from mortgages with 30-year fixed rates into one-year ARMs. The share of new mortgages with adjustable rates, only one-fifth in 2001, had more than doubled by 2004 . An adjustable-rate mortgage shifts the risk of a rise in interest rates from

${ }^{3}$ Federal Reserve Bank of St. Louis Monetary Trends (February 2008): 10. The Taylor Rule formula used there is spelled out on p. 19. The inflation measure is the Fed's currently preferred measure, the Personal Consumption Expenditure deflator. John Taylor noted the Fed's deviation from the Taylor Rule in his 2007 Jackson Hole Symposium paper (Taylor 2007).

${ }^{4}$ As reported by Freddie Mac: www.freddiemac.com/pmms/pmms30.htm. 
the lender to the borrower. Many borrowers who took out ARMs implicitly (and imprudently) relied on the Fed to keep short-term rates low for as long as they kept the mortgage. As is well known, they have faced problems as their monthly payments have reset upward. The shift toward ARMs compounded the mortgage-quality problems arising from other sources such as regulatory mandates.

Because real estate is an especially long-lived asset, and thus has an especially large part of its value depend on the discounting of far-distant future cash flows, its market value rises relative to those of other assets with a fall in the interest rate used for discounting. The dramatic fall in interest rates made 2001 real estate prices seem like bargains. The demand bubble that the Fed created was thereby drawn disproportionately into real estate. Real-estate loans at commercial banks grew at a 12.26 percent compound annual rate during the period from the midpoint of 2003 to the midpoint of $2007 .{ }^{5}$ The Fed-fueled low interest rates and growth of mortgage credit pushed up the demand for and prices of existing houses, and encouraged the construction of new housing on undeveloped land. The housing sector thus exhibited a disproportionate share of the price inflation predicted by the Taylor-rule gap.

Researchers at the International Monetary Fund have provided evidence from simulation studies corroborating the view that the Fed's easy-credit policy (combined with encouragements for riskier mortgage lending) inflated the housing bubble. As they put their findings, "the unusually low level of interest rates in the United States between 2001 and 2003 contributed somewhat to the elevated rate of expansion in the housing market, in terms of both housing investment and the run-up in house prices up to mid-2005." After estimating the sensitivity of U. S. house prices and residential investment to interest rates, they find that "the increase in house prices and residential investment in the United States over the past six years would have been much more contained had short-term interest rates remained unchanged" (Cardarelli et al. 2008: 19, 21). ${ }^{6}$ Even Alan Greenspan, who otherwise protests his innocence, has acknowledged that "the 1 percent rate set in mid-2003... lowered interest rates on adjustable-rate mortgages [ARMs] and may have contributed to the rise in U.S. home prices" (Greenspan 2007).

\footnotetext{
${ }^{5}$ Author's calculation from data in the Federal Reserve Bank of St. Louis FRED series REALLN.

${ }^{6}$ Taylor (2007) arrives at similar findings after running slightly different counterfactual simulations.
} 


\section{Cato Journal}

The excess investment in new housing has left the United States today with an overbuilt housing stock. Assuming that the federal government does not follow proposals (tongue-in-cheek or otherwise) that it should buy up and then raze excess houses and condos, or proposals to admit a large number of new immigrants, we can expect U.S. house prices and construction activity to remain depressed for a few years. The process of adjustment, already well under way but not yet completed, requires house prices to fall and resources (labor and capital) to be released from the construction industry to find more appropriate employment elsewhere. Correspondingly, it requires the book value of existing financial assets based directly or indirectly on housing to be written down and resources to be released from writing and trading mortgages to find more appropriate employment elsewhere. No matter how painful the adjustment processes, delaying them only delays the economy's recovery. Going forward, barring a more fundamental reform of the monetary regime, a monetary policy rule that incorporates asset prices in the measure of inflation may offer the best prospects for reduced asset froth.

\section{The Federal Reserve’s New Post-Bubble Roles}

As a historian of antiquarian monetary institutions, let me take you back to what now seems like the distant past: 2007 .

Before 2008, the Federal Reserve System played the traditional central banking roles of conducting monetary policy and (on very rare occasions, like the day after 9/11) acting as a "lender of last resort." Monetary policy means controlling the quantity of money in pursuit of economic objectives. Acting as a lender of last resort is merely an aspect of monetary policy: It means injecting reserves into the commercial banking system to prevent the quantity of money from contracting - and thereby to protect the economy's payment system-when there is an "internal drain" of reserves (bank runs and the hoarding of cash). The "lender" part of the role's name has long been an anachronism. Central banks in sophisticated financial systems discovered many decades ago that they can inject bank reserves without lending, by purchasing government securities in the open market. By purchasing securities the central bank supports the money stock while avoiding the danger of favoritism associated with making loans to specific banks on noncompetitive terms (Goodfriend and King 1988). By purchasing 
Treasury securities it avoids the potential for favoritism in purchasing other securities.

Before 2008, the Federal Reserve controlled growth in monetary and credit aggregates through such open market operations, using the Fed funds interest rate as an intermediate target for guiding open market operations. Growth in the monetary aggregate that the Fed directly controls, the monetary base, was matched almost exactly by the Fed's accumulation of U.S. Treasury securities, virtually the only financial asset the Fed acquired. The quantity of loans that the Fed made to commercial banks was trivial (less than $\$ 0.5$ billion at the end of 2007 , on a balance sheet of $\$ 800$ billion). Loans to nonbank institutions were out of the question.

In 2008 things changed in a remarkable and worrisome way. In addition to conducting monetary policy, the Fed took on the new role of selectively channeling credit in favored directions. It now makes loans to, and purchases assets from, an array of financial institutions that are not commercial banks and do not issue means of payment. The total of new Fed credits granted-the Federal Reserve's self-financed bailout program — stood by the end of 2008 at $\$ 1.7$ trillion, more than double the size of the Treasury's $\$ 700$ billion bailout authority.

The Fed's weekly balance sheets contain a number of new line items reflecting its newly assumed role as credit allocator. ${ }^{7}$ The list of items appearing on the balance sheet in early 2009, but absent from it in 2007, begins with Mortgage-backed Securities, an entry that first began appearing on the release of January 15 and has grown steadily since. On the balance sheet release of February 5, 2009 (the most recent available at the time of this article's final revision), the Fed's holdings of MBSs stood at $\$ 7$ billion. Second is Term Auction Credit of $\$ 413$ billion, representing 28-day and 84-day loans to banks. Previously loans to commercial banks were basically overnight credits for meeting reserve requirements. Banks were expected to secure longer-term loans from depositors or other private lenders. Third on the list is Primary Dealer and other Broker-Dealer Credit of $\$ 30$ billion, loans to securities dealers. Previously the Fed did not lend to securities dealers. Fourth is the Asset Backed Commercial Paper

${ }^{7}$ The Fed's latest balance sheet is reported weekly, with comparisons to one week and one year ago, in the Fed's H.4.1 release, available at www.federalreserve.gov/ releases/h41. For a detailed discussion of the 23 October 2008 balance sheet, see Hamilton (2008). Each dollar figure reported in the present text is the average of daily figures for the week ended 4 February 2009. 
Money Market Mutual Fund Liquidity Facility at $\$ 17$ billion, loans to banks or bank holding companies for the specific purpose of allowing them to purchase assets from money market mutual funds that are facing redemptions. Previously money-market funds that needed to sell commercial paper were expected to sell it in the money market. Fifth, Credit Extended to American International Group, Inc., life-support loans to the failed insurance giant, amounted to $\$ 39$ billion. Previously the Fed did not lend to insurance companies, nor to financial firms in receivership.

Sixth comes Net Portfolio Holdings of Commercial Paper Funding Facility LLC, an entry that the H.4.1 release describes as loans to "a limited liability company formed [by the Federal Reserve Bank of New York in October 2008] to purchase three-month U.S. dollardenominated commercial paper from eligible issuers and thereby foster liquidity in short-term funding markets and increase the availability of credit for businesses and households." Previously the Fed did not purchase commercial paper or other private securities. Seventh, holding a place on the balance sheet although it had yet to show a non-zero amount, we find Net Portfolio Holdings of LLCs Funded through the Money Market Investor Funding Facility, a similar entry for loans to "a series of limited liability companies...established [by the NY Fed in November 2008] to purchase short-term U.S. dollar-denominated certificates of deposit, bank notes, and outstanding asset-backed commercial paper from eligible issuers." Eighth through tenth are: Net Portfolio Holdings of Maiden Lane $L L C$, an entry representing troubled assets from the portfolio of the former investment bank Bear Stearns that the New York Fed absorbed to sweeten the takeover deal for the benefit of JPMorgan Chase; Net Portfolio Holdings of Maiden Lane II LLC, representing troubled mortgage-backed securities purchased from AIG, and Net Portfolio Holdings of Maiden Lane III LLC, representing troubled collateralized debt obligations purchased from AIG. By holding rather than selling off these assets the Fed is speculating that the market for selling the assets will be better later on. Previously the Fed did not get involved in financial mergers, acquisitions, or life-support operations by taking on troubled assets. The FDIC did, but only in mergers between two insured commercial banks. Bear Stearns was an investment bank, not an insured commercial bank. AIG is an insurance company that no other private firm wants to take over. 
In September 2008, the Federal Reserve began buying federal agency notes-short-term IOUs of Fannie Mae, Freddie Mac, and the Federal Home Loan Banks-from securities dealers. As of 5 February the Fed was holding $\$ 29$ billion of such notes, where it held $\$ 0$ one year ago, though it has held agency debt in the past. Fed loans to commercial banks (listed as primary, secondary, and seasonal credit) are currently at $\$ 67$ billion, up from only $\$ 0.15$ billion a year ago. In total, the Fed's assets have more than doubled in a year's time, from $\$ 874$ billion in February 2008 to an astounding $\$ 1,853$ billion in February 2009.

Meanwhile, off the balance sheet (but recorded as a "memorandum item"), the Fed also runs a Term Securities Lending Facility that has swapped $\$ 120$ billion of its Treasury securities to brokerdealers in exchange for less liquid securities including "highly rated" mortgage-backed securities. Subtracting the swapped-out Treasuries from its balance sheet holdings, the Fed's assets in February 2009 were only 19 percent Treasuries, down from 82 percent one year earlier. Some of the new assets are loans collateralized by mortgagebacked securities, while others have better collateral, but none are as safe as Treasuries. The Fed looks increasingly like a very highly leveraged hedge fund. In the February figures the Fed's equity cushion was down to only 2.2 percent of its assets, so it was leveraged more than 45:1. A year earlier, with a much safer portfolio, the Fed's equity ratio was nearly twice as high at 4.3 percent.

Reflecting the riskiness of some of its new assets, the Fed in October 2008 recorded $\$ 2.7$ billion in losses from mark-downs on the securities held in the New York Fed's Maiden Lane, LLC account (see Hamilton 2008). The book value of the Fed's overall capital dropped by $\$ 2$ billion in the week between 15 October and 22 October, sliding to $\$ 40$ billion from $\$ 42$ billion.

The Federal Reserve's new interventions into financial markets over the past year have proceeded at its own initiative, without precedent, and without congressional oversight. None of the new lending facilities has anything to do with acting as a lender of last resort in the traditional sense of preventing a reduction in bank reserves due to bank runs, or a reduction in the deposit-to-reserves ratio, from shrinking the money stock. Any desired volume of bank reserves can be injected entirely by purchasing Treasury securities. Through all the recent turmoil there has been no shrinking money stock, and 


\section{Cato Journal}

only one brief run on a commercial bank (Indy Mac). Investment banks do not issue checking deposits, are therefore not subject to depositor runs, and are not part of the payment system. Neither are securities dealers. Money-market funds have a limited payment role but have no demandable debts, and therefore are not subject to selfaggravating me-first runs. The Fed's expansions of its lending activities have had nothing to do with protecting the payment system or stabilizing the money supply.

The Fed's new activities instead amount to a grab-bag of ad hoc bailouts. They seem to aim at protecting banks and nonbanks from the consequences of holding portfolios overweighted with mortgagebacked securities, or derivatives based on such securities, while keeping levels of capital inadequate for such portfolios. Attempting such bailouts is a worrisome role for the Fed to take on, especially at its own initiative, without oversight. That the Fed's bailout is "selffinanced" by expanding its own liabilities ("printing" new money) does not mean that it provides a free lunch. It is ultimately financed by the Fed's power to levy an implicit tax on dollar-holders, putting us all at risk of inflationary depreciation of the dollar.

Thus far, because it has not required an appropriation from Congress, the Fed's bailout efforts seem to be enjoying the complete freedom from oversight that Secretary Paulson initially sought for the Treasury's bailout. That should change. No matter how urgently we seek to avoid a financial meltdown, there is no good reason to embrace a constitutional meltdown. It is time for a public debate on the wisdom of the Fed's remarkable departure from its traditional roles. Would calling the Fed to account for its actions be a violation of the Fed's traditional independence? Unfortunately Chairman Bernanke forfeited that independence months ago.

\section{References}

Cardarelli, R.; Monacelli, T.; Rebucci, A.; and Sala, L. (2008) "The Changing Housing Cycle and the Implications for Monetary Policy." In World Economic Outlook: Housing and the Business Cycle, Chap. 3. Washington: World Bank (April).

Goodfriend, M., and King, R. G. (1988) "Financial Deregulation, Monetary Policy, and Central Banking." In W. S. Haraf and R. Kushmeider (eds.) Restructuring Banking and Financial Services in America. Washington: American Enterprise Institute. 
Greenspan, A. (2007) "The Roots of the Mortgage Crisis." Wall Street Journal (12 December).

Hamilton, J. D. (2008) "The Federal Reserve's Balance Sheet." Econbrowser blog (25 October): www.econbrowser.com/ archives/2008/10/the_federal_res.html.

Selgin, G. (1997) Less than Zero: The Case for a Falling Price Level in a Growing Economy. London: Institute of Economic Affairs.

Taylor, J. B. (2007) "Housing and Monetary Policy." Paper presented at the Federal Reserve Bank of Kansas City Symposium on "Housing, Housing Finance, and Monetary Policy." Jackson Hole, Wyo. (30 August-1 September). Available at www.kc.frb. org/PUBLI CAT/SYMPOS/2007/PDF/Taylor_0415.pdf.

White, L. H. (2008) "How Did We Get into This Financial Mess?" Cato Briefing Paper, No. 108 (18 November). 